\title{
GAMBARAN PENGEMBALIAN DOKUMEN REKAM MEDIS RAWAT INAP RUANG VII TRIWULAN IV TAHUN 2013 DI RUMAH SAKIT UMUM DAERAH TASIKMALAYA
}

\author{
Ulfah Fauziah ${ }^{1}$, Ida Sugiarti ${ }^{2}$ \\ ${ }^{1}$ Mahasiswa D IV Politeknik Piksi Ganesha, ulfahfauziaah@gmail.com \\ ${ }^{2}$ Dosen Program Studi D III PIKES Poltekkes Tasikmalaya, sugiarti.ida@gmail.com
}

\begin{abstract}
The purpose of the research is to know the plots of returning of medical recording document of hospitalizing at RSUD Tasikmalaya that is suitable with the SOP, to know the plots of returning the medical recording document of hospitalizing at RSUD Tasikmalaya that is not suitable with SOP, to know the descriptionof returning the medical recording unit which was late from room VII in 2013 at RSUD Tasikmalaya and to know the description of returning the medical recording document of hospitalizing from the ward to the medical recording unit which was on time from room VII in 2013 at RSUD Tasikmalaya.

The kind of research is descriptive by retrospective approach, the method is gathering data observation. Population and sample of this research are 714 sample of medical recording document of hospitalizing at room VII and about 256 sample of medical recording document at room VII by using random sampling technique. The data analysis is used univariate analysis.

The result of the research shows that the returning of medical recording document of hospitalizing at room VII with the higher percentages of the returning of medical recording unit on time is in October as much as $78,82 \%$ from the 67 documents and higher percentage of the late returning of medical recording is in December as much as $84,88 \%$ from the 73 the total of the documents.

In general, the returning of medical recording document of hospitalizing at room VII is equal with the plots of the returning of medical recording document, the maximum time is used for the returning of medical recording is about 14 days.
\end{abstract}

The key words: The late of returning of medical recording document

\section{PENDAHULUAN}

Penyelenggaraan rekam medis adalah merupakan proses kegiatan yang dimulai pada saat diterimanya pasien di rumah dilanjutkan dengan kegiatan pencatatan data medis pasien oleh dokter atau dokter gigi dan tenaga kesehatan lainnya, yang memberikan pelayanan kesehatan langsung kepada pasien. Proses pengolahan rekam medis terdiri dari beberapa tahapan antara lain dilakukannya assembling, koding, indeksing dan filling (Depkes, 2006).

Dokumen rekam medis rawat inap yang telah selesai dipakai dari ruang rawat inap harus segera dikembalikan ke unit rekam medis pada bagian assembling, setiap dokumen rekam medis yang kembali dari ruang rawat inap ke unit rekam medis pada bagian assembling harus disusun sesuai ketentuan yang berlaku.
Kegiatan assembling diantaranya: merakit dokumen rekam medis, mengecek kelengkapan pengisian dokumen rekam medis dan formulir yang harus ada pada dokumen rekam medis. Apabila dokumen rekam medis telah diterima dari ruang rawat inap dengan menggunakan buku ekspedisi pengembalian dokumen rekam medis, bagian assembling akan mencatat pada buku register, semua dokumen rekam medis yang masuk sesuai tanggal masuk ke bagian assembling dan tanggal pasien pulang (Budi, 2011). Apabila dokumen rekam medis rawat inap lengkap maka dapat dilakukan pengkodean dan indeksing setelah semua diselesaikan maka dokumen rekam medis rawat inap disimpan ke rak penyimpanan atau filling. Jika dokumen rekam medis rawat inap tidak lengkap maka harus dikembalikan ke ruang rawat inap dengan ketentuan waktu yang berlaku. Batas waktu penyelesaian pengisian 
dokumen rekam medis pasien rawat inap 1 X 24 jam setelah pasien pulang dari rumah sakit dan berkas rekam medis harus segera dikembalikan ke unit rekam medis pada bagian assembling (Tim Penyusun Pedoman Penyelenggaraan Rekam Medis RSUD Tasikmalaya Jilid I, 2011). Keterlambatan pengembalian dokumen rekam medis rawat inap pada bagian assembling dikatakan terlambat jika $>1$ X 24 jam. Fakta di lapangan, berdasarkan hasil wawancara dengan Kepala Unit Rekam Medis dan hasil observasi selama Praktek Lapangan, jarang sekali dokumen bisa kembali dalam waktu $1 \mathrm{X}$ 24 jam, sehingga pihak rumah sakit memberikan toleransi sampai dengan 14 hari untuk pengembalian dokumen rekam medis, selain itu terdapat kendala teknis, diantaranya petugas Tata Usaha yang berada di ruangan juga merangkap mengurus keuangan sehingga ikut menghambat pengembalian dokumen rekam medis tersebut.

Berdasarkan hasil penelitian di bagian assembling Rumah Sakit PKU Muhammadiyah Yogyakarta, Sari (2009), menunjukan persentase keterlambatan tertinggi pada bulan Pebruari sebanyak 53,62\% dari total 138 dokumen yang dikembalikan pada bagian assembling. Persentase penyebab keterlambatan penyerahan dokumen rekam medis yang tertinggi terdapat pada tingkat kedisiplinan dokter dalam pengisian data pada dokumen rekam medis (diagnosis dan tanda tangan) sebanyak $80 \%$. Hasil penelitian menunjukan bahwa di rumah sakit terjadi keterlambatan dalam penyerahan dokumen rekam medis. Secara garis besar fakta yang ada dalam hasil penelitian menggambarkan bahwa keterlambatan dalam penyerahan dokumen rekam medis masih memiliki angka persentase yang cukup besar.

Hal itu terjadi juga di Rumah Sakit Umum Daerah Tasikmalaya. Pengembalian dokumen rekam medis rawat inap di Rumah Sakit Umum Daerah Tasikmalaya masih terjadi keterlambatan. Hal ini menyebabkan terlambatnya pembuatan laporan, juga terjadi penumpukan dokumen rekam medis. Berdasarakan standar prosedur operasional Rumah Sakit Umum Daerah Tasikmalaya setiap dokumen rekam medis pasien rawat inap harus segera dikembalikan ke unit rekam medis pada bagian assembling dalam kurun waktu 1 X 24 jam setelah pasien pulang. Masalah lain yang terhambat akibat keterlambatan pengembalian dokumen rekam medis adalah penyajian data, yang dijadikan sebagai pengambil kebijakan dan perencanaan rumah sakit selanjutnya.

Berdasarkan hasil survei pendahuluan pada tanggal 22 Februari 2013 diperoleh data pembanding dari ruang unit rekam medis pada bagian assembling terdapat keterlambatan pengembalian dokumen rekam medis di beberapa ruang rawat inap Rumah Sakit Umum Daerah Tasikmalaya. Keterlambatan pengembalian dokumen rekam medis rawat inap yang tertinggi di ruang rawat inap Rumah Sakit Umum Daerah Tasikmalaya, dengan peringkat persentase pertama tertinggi terdapat di ruang VII triwulan ke III tahun 2012 sebanyak 76,09\%. Berdasarkan latar belakang di atas maka peneliti tertarik untuk mengambil judul "Gambaran Pengembalian Dokumen Rekam Medis Rawat Inap Ruang VII Triwulan IV Tahun 2012 Di Rumah Sakit Umum Daerah Tasikmalaya".

\section{METODE}

Jenis penelitian ini adalah deskriptif dengan pendekatan retrospektif. Penelitian dilaksanakan di Unit rekam medis bagian assembling Rumah Sakit Umum Daerah Tasikmalaya. Waktu penelitian tanggal 6 sampai 31 Mei 2013.

Populasi dalam penelitian ini adalah dokumen rekam medis rawat inap ruang VII triwulan IV tahun 2012 sebanyak 714 dokumen rekam medis. Besar sampel 256 dokumen. Pengambilan sampel dilakukan dengan teknik random sampling. Instrumen penelitian ini adalah pedoman observasi berupa lembar checklist dan lembar observasi.

Analisis data yang digunakan yaitu dengan cara analisis univariat hanya meneliti satu variabel saja dengan melihat prosentase dan hasil keterlambatan pengembalian dokumen rekam medis rawat inap.

\section{HASIL}

Seksi rekam medis RSUD Kota Tasikmalaya mengolah data medis dan non medis melalui proses sensus harian dan proses lainnya diantaranya adalah assembling (perakitan kembali dokumen rekam medis), koding dan indeksing. 


\section{Bagan 1. Alur Pengembalian Dokumen Rekam} Medis Rawat Inap

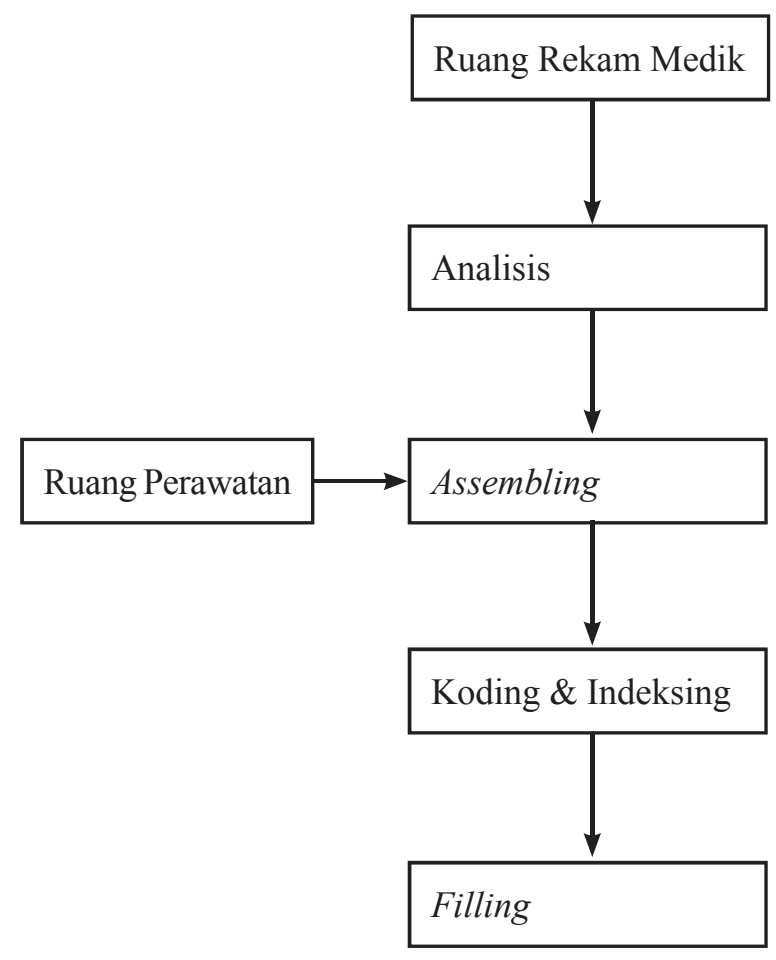

Berdasarkan Standar Oprasional Prosedur (SOP) di Rumah Sakit Umum Daerah Taikmalaya pengembalian dokumen rekam medis rawat inap harus dikembalikan ke unit rekam medis pada bagian assembling dalam kurun waktu 1X24 jam setelah pasien pulang. Berbagai kendala di lapangan, seperti terbatasnya SDM Rekam Medis dan petugas TU ruangan yang bertugas rangkap mengurus keuangan, membuat pihak Rumah Sakit memberikan toleransi batas 14 hari untuk pengembalian, sehingga penelitian ini menggunakan batas 14 hari untuk waktu pengembalian.

Hasil penelitian yang telah dilakukan pengembalian dokumen rekam medis rawat inap di Rumah Sakit Umum Daerah Tasikmalaya pada ruang VII sebagian besar dokumen dikembalikan dalam kurun waktu 14 hari, tetapi masih ada yang melebihi waktu yang ditetapkan terutama pada periode bulan Desember.

Dokumen rekam medis yang akan dikembalikan harus dilengkapi terlebih dahulu oleh petugas ruangan serta dokumen tersebut disusun sesuai dengan nomor urut catatan medis, dokumen tersebut ditulis dalam buku ekspedisi ruangan berupa nomor rekam medis dan nama pasien. Setelah dilengkapi dan ditulis pada buku ekspedisi ruangan maka dokumen dikembalikan ke unit rekam medis pada bagian assembling. Dokumen yang telah diterima dengan menggunakan buku ekspedisi pengembalian dokumen rekam medis rawat inap, akan di cek kembali oleh petugas dan dicocokan dengan sensus harian ruang VII. Apabila ditemukan dokumen rekam medis yang belum dikembalikan maka petugas akan mencatat pada buku register pasien pulang. Petugas mencatat pada buku ekspedisi serta ditandatangani oleh petugas bagian assembling. Hasil penelitian, masih ditemukan pencatatan pada buku register yang tidak sesuai dengan tanggal pasien pulang sehingga pencatatan dokumen rekam medis masih tidak teratur dan menyulitkan pencarian dokumen kembali.

Tabel 1. Gambaran Pengembalian Dokumen Rekam Medis Rawat Inap Ruang VII Triwulan IV Tahun 2012

\begin{tabular}{|c|c|c|c|c|c|c|c|}
\hline \multirow{2}{*}{ No } & \multirow{2}{*}{ Keadaan Dokumen Rekam Medis } & \multicolumn{2}{|c|}{ Oktober } & \multicolumn{2}{|c|}{ November } & \multicolumn{2}{|c|}{ Desember } \\
\hline & & $\mathbf{N}$ & $\%$ & $\overline{\mathbf{N}}$ & $\%$ & $\overline{\mathbf{N}}$ & $\%$ \\
\hline 1. & $\begin{array}{l}\text { Dokumen rekam medis yang dikembalikan tepat } \\
\text { waktu yang ditetapkan (14 Hari) }\end{array}$ & 67 & $78,82 \%$ & 62 & $72,94 \%$ & 13 & $15,11 \%$ \\
\hline 2. & $\begin{array}{l}\text { Dokumen rekam medis yang dikembalikan tidak } \\
\text { tepat waktu yang ditetapkan ( }>14 \text { Hari) }\end{array}$ & 18 & $21,17 \%$ & 23 & $27,05 \%$ & 73 & $84,88 \%$ \\
\hline \multicolumn{2}{|c|}{ Jumlah } & 85 & $100 \%$ & 85 & $100 \%$ & 86 & $100 \%$ \\
\hline
\end{tabular}

\section{Sumber : Data Primer}

Tabel diatas menunjukan persentase pengembalian dokumen rekam medis rawat inap ruang VII di Rumah Sakit Umum Daerah Tasikmalaya, pengembalian dokumen yang tidak tepat waktu presentase tertinggi ada pada bulan Desember sebanyak $84,88 \%$ dari total 86 dokumen rekam medis yang dikembalikan ke bagian assembling dan pengembalian dokumen rekam medis yang tepat waktu tertinggi ada pada bulan Oktober sebanyak $78,82 \%$ dari total 85 dokumen rekam medis yang dikembalikan pada bagian assembling. 


\section{PEMBAHASAN}

1. Alur pengembalian dokumen rekam medis rawat inap dari bangsal ke ruang rekam medis Rumah Sakit Umum Daerah Tasikmalaya

Unit rekam medis di Rumah Sakit Umum Daerah Tasikmalaya dalam pengembalian dokumen rekam medis pasien rawat inap terdapat pihak yang terkait di dalamnya yaitu perawat, dokter dan bagian assembling. Dokumen rekam medis pasien rawat inap harus segera dikembalikan ke unit rekam medis pada bagian assembling dalam kurun waktu 14 hari batas waktu pengembalian maksimal setelah pasien pulang sesuai dengan standar oprasional prosedur yang telah ditetapkan pihak rumah sakit, yaitu batas waktu maksimal 14 hari. Standar oprasional prosedur yang ada belum pernah diperbaharui. Penelitian yang telah dilakukan, menggunakan batas waktu 14 hari sesuai dengan standar oprasional prosedur Rumah Sakit Umum Daerah Tasikmalaya.

Di dalam SOP Rumah Sakit, dokumen rekam medis yang akan dikembalikan harus dilengkapi terlebih dahulu oleh petugas ruangan dan dokumen tersebut disusun sesuai dengan nomor urut catatan medis tetapi kenyataan di RSU tersebut, hal ini jarang dilaksanakan karena kesibukan petugas ruangan. Dokumen tersebut ditulis dalam buku ekspedisi ruang VII berupa nomor rekam medis dan nama pasien. Setelah dilengkapi dan ditulis pada buku ekspedisi ruangan maka dokumen dikembalikan ke unit rekam medis pada bagian assembling, Dokumen rekam medis yang belum dikembalikan melewati batas waktu pengembalian yang telah ditetapkan maka terjadi keterlambatan pengembalian dokumen rekam medis rawat inap, yang dapat menghambat pada pekerjaan lainnya.

Penelitian yang telah dilakukan di Rumah Sakit Umum Daerah Tasikmalaya pada unit rekam medis bagian assembling sudah mempunyai Standar Oprasional Prosedur (SOP) atau alur pengembalian dokumen rekam medis rawat inap, tetapi pelaksanaannya belum sesuai dengan prosedur. Idealnya di dalam alur dan prosedur juga dicantumkan batas waktu pengembalian 1 X 24 jam setelah pasien pulang harus diserahkan ke ruang assembling, bila masih terdapat ketidaklengkapan maka akan dikembalikan ke ruang rawat inap dan harus dikembalikan lagi dalam jangka waktu $2 \mathrm{X}$
24 jam. Selanjutnya apabila masih terdapat ketidaklengkapan maka akan dikembalikan lagi ke ruang perawatan, dan baru diberikan waktu 14 hari untuk kelengkapan. Tetapi tentu dapat dimaklumi, karena Rumah Sakit juga terkendala oleh sumber daya manusia yang ada.

Keterlambatan pengembalian mengakibatkan penumpukan dokumen rekam medis rawat inap juga pada akhirnya menjadi beban petugas assembling. Dalam pencatatan pada buku register belum sesuai dengan tanggal pasien pulang sehingga pencatatan dokumen rekam medis masih tidak teratur dan dapat menyulitkan apabila dokumen tersebut dibutuhkan kembali untuk pengobatan selanjutnya. Ketidakteraturan pencatatan dokumen rekam medis rawat inap karena pengembalian dokumen rekam medis tidak sesuai dengan tanggal pasien pulang dan dikembalikan melewati waktu yang telah ditetapkan sehingga terjadi keterlambatan pengembalian dokumen rekam medis rawat inap ruang VII di Rumah Sakit Umum Daerah Tasikmalaya.

2. Gambaran pengembalian dokumen rekam medis rawat inap dari ruang VII ke Unit Rekam Medis.

Berdasarkan hasil penelitian di Rumah Sakit Umum Daerah Tasikmalaya di unit rekam medis bagian assembling diketahui bahwa tingkat keterlambatan pengembalian dokumen rekam medis rawat inap ruang VII dengan persentase tertinggi pada bulan Desember sebanyak $84,88 \%$ dokumen yang terlambat dikembalikan pada bagian assembling, dengan waktu pengembalian dokumen rekam medis > 14 hari setelah pasien pulang.

Pengembalian dokumen rekam medis yang melebihi waktu yang telah ditetapkan terjadi kemungkinan karena dokumen rekam medis rawat inap belum lengkap atau petugas ruangan yang tidak disiplin sehingga dapat menjadi beban petugas dalam pengolahan data. Dampak dari keterlambatan pengembalian dokumen rekam medis rawat inap dari ruang VII menyebabkan keterlambatan dalam pengolahan data untuk laporan rumah sakit, dokumen rekam medis rawat inap tidak tersimpan pada rak penyimpanan dokumen sehingga menyulitkan pencarian dokumen, sedangkan bagi pasien akan mempengaruhi dalam proses pengobatan selanjutnya. Hal ini akan mempengaruhi informasi yang dilaporkan kepada pimpinan 
rumah sakit menjadi tidak tepat waktu dan tidak akurat sehingga menghambat kefektifan pengambilan keputusan manajemen rumah sakit serta menyebabkan keterlambatan pembuatan laporan yang dikerjakan oleh petugas.

Berdasarkan hasil wawancara dengan Kepala Unit Rekam Medis, nilai keterlambatan pengembalian dokumen rekam medis rawat inap pada bulan Desember/akhir tahun meningkat tinggi karena kesibukan pada akhir tahun dalam pembuatan laporan tahunan rumah sakit sehingga pengolahan data terabaikan.

\section{SIMPULAN}

Di bawah ini adalah simpulan berdasarkan hasil penelitian di Rumah Sakit Umum Daerah Tasikmalaya.

1. Terdapat Alur Pengembalian dokumen rekam medis rawat inap dari bangsal ke unit rekam medis yang sesuai dengan standar oprasional prosedur di Rumah Sakit Umum Daerah Tasikmalaya, dokumen rekam medis rawat inap dikembalikan ke unit rekam medis bagian assembling sesuai dengan standar oprasional prosedur yang telah ditetapkan yakni selama 14 hari pengembalian maksimal.

2. Pengembalian dokumen rekam medis rawat inap dari ruang perawatan ke unit rekam medis yang tepat waktu ke unit rekam medis bagian assembling dengan jumlah presentase tertinggi ada pada bulan Oktober 2012 dengan nilai $78,82 \%$ sedangkan jumlah presentase pengembalian dokumen rekam medis rawat inap yang terendah dengan jumlah 15,11\%.

3. Pengembalian dokumen rekam medis rawat inap dari ruang perawatan ke unit rekam medis yang terlambat dari ruang VII di Rumah Sakit Umum Daerah Tasikmalaya, ke unit rekam medis bagian assembling engan jumlah presentase tertinggi terdapat pada bulan Desember dengan nilai $84,88 \%$ sedangkan jumlah presentase pengembalian dokumen rekam medis rawat inap yang terendah dengan jumlah $21,17 \%$.

\section{DAFTAR PUSTAKA}

Anonim. 2011. Buku Pedoman Penyelenggaraan Rekam Medis Rumah Sakit Umum Daerah Tasikmalaya Jilid I Revisi I. Rumah Sakit Umum Daerah Tasikmalaya : Tidak diterbitkan.
Anonim. 2011. Buku Pedoman Penyelenggaraan Rekam Medis Rumah Sakit Umum Daerah Tasikmalaya Jilid II Revisi I. Rumah Sakit Umum Daerah Tasikmalaya : Tidak diterbitkan.

Budi, Savitri Citra. 2011. Manajemen Unit Kerja Rekam Medis. Yogyakarta : Quantum Sinergis Media.

DepKes RI. 2006. PengelolaanRekam Medis Rumah Sakit di Indonesia Revisi I. Jakarta.

Hastuti. 2009. Analisis Keterlambatan Pengembalian Dokumen Rekam Medis Pasien Rawat Inap di Bagian Assembling di RSU PKU Muhammadiyah Delanggu Triwulan I Tahun 2009. Karanganyar : Apikes. FDF.

Hatta, Gemala. 2008. Pedoman Manajemen informasi Kesehatan di Sarana Pelayanan Kesehatan. Jakarta : UI Press.

Notoatmojo, Soekidjo. 2005. Metodologi Penelitian Kesehatan. Jakarta : Rhineka Cipta.

Notoatmojo, Soekidjo. 2010. Metodologi Penelitian Kesehatan. Jakarta : Rhineka Cipta.

Peraturan Menteri Kesehatan Republik Indonesia Nomor 269/MENKES/PER/III/2008 tentang Rekam Medis.

Riyanto, Agus. 2011. Aplikasi Metodologi Penelitian Kesehatan. Yogyakarta : Nuha Medika.

Sari, Dwi Hastuti. 2009. Analisis Keterlambatan Pengembalian Dokumen Rekam Medis Pasien Rawat Inap di Bagian Assembling RSU PKU Muhammadiyah Delanggu Triwulan I Tahun 2009. Tidak diterbitkan

Shofari, Bambang. 2002. Modul Pembelajaran Sistem dan Prosedur Pelayanan Rekam Medis. Semarang : PORMIKI.

Sugiyono. 2008. Metode Penelitian Kuantitatif Kualitatif Dan $R \& D$. Bandung : Alfabeta. 